\title{
The Development of Primate Raiding: Implications for Management and Conservation
}

\author{
Shirley C. Strum
}

Received: 24 December 2008 / Accepted: 06 November 2009 /

Published online: 8 January 2010

(C) The Author(s) 2009. This article is published with open access at Springerlink.com

\begin{abstract}
Ecosystems and habitats are fast becoming human dominated, which means that more species, including primates, are compelled to exploit new human resources to survive and compete. Primate "pests" pose major management and conservation challenges. I here present the results from a unique opportunity to document how well-known individuals and groups respond to the new opportunity to feed on human foods. Data are from a long-term study of a single population in Kenya at Kekopey, near Gilgil, Kenya. Some of the naïve research baboons became raiders while others did not. I compare diet, activity budgets, and home range use of raiders and nonraiders both simultaneously, after the incursion of agriculture, and historically compared to the period before agriculture appeared. I present measures of the relative benefits (female reproduction) and costs (injuries, mortality, and survivorship) of incorporating human food into the diet and discuss why the baboons raid and their variations in raiding tendencies. Guarding and chasing are evaluated as control techniques. I also suggest conflict mitigation strategies by identifying the most likely options in different contexts. I end with a proposal for a rapid field assessment of human wildlife conflict involving primates.
\end{abstract}

Keywords baboons $\cdot$ control techniques $\cdot$ foraging strategy $\cdot$ Kenya primate raiding rapid field assessments

\footnotetext{
S. C. Strum $(\square)$

Uaso Ngiro Baboon Project (previously Gilgil Baboon Project), Nairobi 00200, Kenya

e-mail: sstrum@africaonline.co.ke

S. C. Strum

Department of Anthropology, University of California, San Diego, La Jolla, CA 92093-0532, USA

S. C. Strum

Institute of Primate Research, Karen, Nairobi 00502, Kenya
} 


\section{Introduction}

Primates today are threatened by the same processes that make other biodiversity vulnerable, the "evil quartet" of habitat loss and fragmentation, overkill, introduced species, and chains of extinction (Borgerhoff Mulder and Coppolillo 2005; Cowlishaw and Dunbar 2000; Diamond 1984; Oates 1999; Terborgh et al. 2002). However, direct conflict between humans and nonhuman primates is fast becoming as serious a concern for some species and some populations as habitat loss and the bushmeat trade (Rose 2002). The source of this conflict is most often primate "cropraiding" as agricultural lands expand (Cowlishaw and Dunbar 2000; Paterson and Wallis 2005; see Table I, pp. 4-8 in Lee and Priston 2005). We know very little about the problem of primates in the matrix, particularly in the agricultural matrix (Cowlishaw and Dunbar 2000; Siex 2005), not just because crop raiding is recent in many developing countries ( $c f$. Sprague 2002) but also because the principles that guided research agendas have, in the past, shunned such studies. There were 2 exceptions. Richard et al. (1989) classified some primates as "weed" species, primates that flourish in secondary growth habitats created by human disturbance. In 1994, Biquand and Gautier introduced the idea of commensal primates, referring to those that live in close association with humans (Biquand and Gautier 1994). However, the concepts and research languished until recently when the term primate commensalism was revived (Paterson and Wallis 2005) as way to address conflict without using the pejorative term pest "in the interests of conservation of primates" (Paterson 2005a, p. xvi).

The renewed interest results from the accelerating transformation of nature (Diamond 1989; Oates 1999; Terborgh et al. 2002) toward human-dominated

Table I Mean group composition for the Raider (WBY) and Nonraider (PHG) troops from 1981 through 1984 (*January to September, 1984 only; ** July to December, 1981 only)

\begin{tabular}{|c|c|c|c|c|c|c|c|c|}
\hline & \multicolumn{4}{|c|}{ Pumphouse Gang (PHG) } & \multicolumn{4}{|c|}{ WABAYA (WBY) } \\
\hline & 1981 & 1982 & 1983 & $1984 *$ & $1981^{* *}$ & 1982 & 1983 & $1984 *$ \\
\hline \multicolumn{9}{|l|}{ Males } \\
\hline Adults & 4 & 1 & 3 & 4 & 1 & 3 & 3 & 3 \\
\hline Subadults & 7 & 7 & 7 & 7 & 4 & 2 & 1 & 2 \\
\hline Juveniles & 13 & 12 & 13 & 11 & 4 & 4 & 5 & 5 \\
\hline Infants & 9 & 9 & 7 & 7 & 4 & 5 & 6 & 8 \\
\hline \multicolumn{9}{|l|}{ Females } \\
\hline Adults & 15 & 14 & 19 & 18 & 6 & 9 & 9 & 10 \\
\hline Subadults & 9 & 10 & 5 & 4 & 3 & 1 & 1 & 0 \\
\hline Juvenile & 9 & 7 & 6 & 7 & 0 & 0 & 1 & 2 \\
\hline Infants & 6 & 8 & 8 & 6 & 1 & 3 & 3 & 3 \\
\hline Total & 70 & 68 & 68 & 64 & 23 & 27 & 29 & 33 \\
\hline
\end{tabular}

PHG/WBY

*1984 (January-September 1984)

**1981 (July-December 1981) 
ecosystems (Vitousek et al. 1997) and their consequences. These scientific and global trends have legitimized the study of primate-human conflict, stimulating new studies. Some have quantified crop damage and investigated the human dimension of raiding, particularly local people's attitudes toward the raiders and conservation (Chalise and Johnson 2005; Chism 2005; Hill 1997, 2000, 2005; Horrocks and Baulu 1994). One shortcoming of these studies, as Siex (2005) noted, is that they are conducted after crop-raiding became a problem and therefore cannot explain the causal mechanisms from the primate raiders' point of view.

I here provide data collected $>25 \mathrm{yr}$ ago from one of the earliest systematic studies of crop raiding primates. I return to these data because of the growing interest in primate raiding and because no other study has had the opportunity to document the shift to a raiding lifestyle in a well studied but naive group of primates. This is also the only study to assemble the complete chain of raider costs and benefits: from food to activity budgets to growth, death, and reproduction (for costs or benefits see Altmann and Muruthi 1988; Boulton et al. 1996; Bourg et al. 1994; Forthman 1986a, b; Forthman-Quick and Demment 1988; Muruthi et al. 1991; Saj et al. 1999a, b). I have already argued that primate raiding has to be viewed as a foraging strategy (Strum 1991, 1993, 1994 [and see Richard et al. 1989; Siex 2005]). In this analysis I explore the benefits and the costs of raiding using data on diet, activity budgets, and home range utilization of raiders and nonraiders. I contrast the raiding lifestyle with that of nonraiders. Costs and benefits of incorporating human food into the diet are assessed in terms of female reproduction and rates of injury, death, and infant survivorship. Change in female reproduction is one area to look for evolutionary consequences of the proximate change in raider behavior (Bercovitch 1987; Bercovitch and Strum 1993; Smuts and Nicholson 1989). Age at first reproduction is known to be sensitive to ecological conditions (food availability and food competition: Strum and Western 1982). Raiding is also thought to be more dangerous than foraging naturally (Altmann and Muruthi 1988; Forthman-Quick and Demment 1988). One measure of risk is baboon injuries. Comparisons combine a unique longitudinal perspective with the standard cross-sectional approach (Altmann and Muruthi 1988; Else et al. 1986; Fa 1988; Forthman 1986a, b; Warren et al. 2007). They are situated within previous analyses of female fecundity and food availability (Strum and Western 1982), nutrition and growth (Strum 1991), and male reproductive strategies (Strum 1993). I use these data to understand why some baboons shifted foraging strategy and show why traditional techniques of guarding and chasing succeed or fail. Data on variation in raiding tendencies suggest that raiding wasn't inevitable. I outline minimum requirements of new control methods based on insights from this study. Finally, I use this study to make practical suggestions for rapid field assessment of the management of primate raiders.

\section{Methods}

Study Site and Focal Groups

The 2 wild baboon troops of this study were part of a long-term research project on savanna baboons that began in 1970 on Kekopey Ranch near Gilgil Kenya (Harding 
1976; Strum 1975). The area had a large complement of wildlife, including baboons, as well as cattle (Blankenship and Qvortrup 1974). The first group, the Pumphouse Gang (PHG), had been under continuous observation since 1970. The second troop, Wabaya (WBY), resulted from fission of Pumphouse that was complete by July 1981. Wabaya, the daughter troop, was composed of young adult and subadult male raiders and young adult and subadult females that associated with them. The composition of the groups is given in Table I.

Farming intruded onto Kekopey in 1979, when the baboons' previous range was sold to an agricultural cooperative. Small farms appeared in 1980. The previous natural diet of the baboons in this population consisted of grasses, herbs, fruits, flowers, and seeds harvested from the herb, shrub, and tree layers. The diet also included insects and bird and mammalian prey (Forthman-Quick and Demment 1988; Harding 1976; Strum 1975). Land-use changes made human food available; it was added to the diet in late 1980 (Eley et al. 1989; Musau and Strum 1984; Oyaro and Strum 1984). Poor rainfall meant that even by $1984<25 \%$ of the area was under cultivation. Conflict between farmers and baboons was serious enough by July, 1981, that I began an examination of the development of crop-raiding. The study started after raiding had already begun. The research ended in August 1984 when 2 of the troopsPumphouse and Wabaya-were translocated (Strum 2005; Strum and Southwick 1986).

\section{Types of Data}

We followed the study groups daily. The primary data consist of information on diet and activity budgets from scan samples taken as either all-day or half-day follows done on a rotational basis between the troops. I eliminated scans in which $\leq 50 \%$ of the troop were seen, regardless of the reasons. The procedure involved $210-\mathrm{min}$ scans per hour during which each individual was identified by its unique 2-letter code and by its activity. The 29 distinct activity codes have been combined into 4 general categories for this analysis: Feeding/Foraging, Traveling, Resting, and Social. The nonraider group was 2-3 times the size of the raider group (Table I) which might bias the probability of socializing. Therefore, I also normalized rates of "social" for the size of group (per capita) instead of only as a proportion of the total budget. If a baboon was feeding, we also recorded the identity of the food: 36 plant species and 9 plant parts plus animal matter and human foods. Foods are collapsed into 4 major categories for the ecological and chronological analysis: human food, grasses, herbs, and other. For the more refined analysis, I categorized foods as: grasses, herbs, bushes, trees, animal matter, human food, and miscellaneous foods.

I did not use all of the data collected. Instead, I included data with the greatest ecological contrast based on rainfall and herb layer biomass. Six chronological ecological periods between July 1981 and September 1984 were selected for tracking the development and changes in crop raiding (Table II). There are 3 low biomass periods and 3 high biomass periods. The conditions from July 1981 (when the study began) to the end of 1981 constitute 1 above average (high biomass) ecological period and the earliest systematic data on crop-raiding. This was followed by 2 average years, 1982 and 1983, each with two ecological periods, one high and one low biomass. Finally, 1984 was a drought year, with only 1 ecological period, 
Table II Ecological periods from 1981 through 1984 used in the comparisons of Raiders and Nonraiders

\begin{tabular}{lllc}
\hline Year & Season & Selected months & Gilgil mean biomass $\left(\mathrm{g} / \mathrm{m}^{2}\right)$ \\
\hline 1981 High & High biomass & July & 364.61 \\
& High biomass & August & 183.22 \\
& High biomass & September & 112.26 \\
& High biomass & October & 118.69 \\
& Low biomass & March & 55.72 \\
& Low biomass & April & 59.82 \\
& High biomass & November & 130.18 \\
& High biomass & December & 147.96 \\
& Low biomass & March & 57.72 \\
& Low biomass & April & 62.47 \\
& High biomass & May & 113.79 \\
& High biomass & June & 109.66 \\
& Low biomass & March & 61.59 \\
Low biomass & April & 45.10 \\
Low biomass & May & 38.22 \\
Low biomass & June & 37.65 \\
& & & \\
& & &
\end{tabular}

low biomass. Comparisons included biomass conditions within years and across years as well as the chronological development of activity budgets and diet.

There are 7048 scans in this analysis, which yielded 131,508 data points for activities and 41,694 data points for diet.

I calculated birth patterns and interbirth intervals from a total of 122 births of infants that survived $>6$ mo of age (survival IBI; Altmann et al. 1977; Smuts and Nicholson 1989; Strum and Western 1982). Fifty-six are from the study period and 66 births are from the 4 years before agricultural settlement. Another way to assess reproductive potential is to compare the direction of change in successive IBI for females that remained in the same age class. Female age classes follow previous analyses of reproduction in this population (Strum and Western 1982): 1) primparous (5.5-8 yr of age), 2) young multiparous (8.0-12.0 yr of age), 3) middle-aged multiparous (12.0-16.0 yr of age), 4) old multiparous (16.0-20.0 yr of age), and 5) old ( $>20$ yr of age). The raider troop, Wabaya (WBY), lacked a full complement of female age classes.

Although fecundity is an important reproductive indicator, I could not include it in this analysis. Fecundity is normally calculated based on female births per female day (Caughley 1977) but because raider females had mostly sons during this relatively short study, it was hard to calculate their fecundity for comparison to nonraider females. Also, I could not calculate age at first reproduction for infants born to raider mothers because the troop was translocated before infants born under the new conditions reached menarche or first birth (Strum and Western 1982). Most of the first births in this study reflect preceding, natural foraging periods. To enlarge the sample, I also calculated the age of first reproduction after translocation for infants born to females in the previous raiding troop. Information on the age at first 
reproduction is available for 6 females in the raider troop that were born before raiding began but part of their growth occurred while the females were raiders (Strum 1991). These females are matched with 13 nonraider females whose first infant was born during the raiding study.

Mortality patterns are based on 153 deaths of known causes classified as natural or human related (Strum 2005). Natural deaths included illness, accident, and injury. No predation was recorded, reflecting the routine removal of large mammalian predators (Blankenship and Qvortrop 1974; Strum 1975). Settlement of the area caused human-related baboon deaths, including reprisal killings for raids on farms and accidents related to the presence of people such as death by touching highvoltage power lines. Local people did not kill baboons for food. Of the 153 deaths, 132 occurred during the study and are compared to 21 deaths in the period before agriculture. The analysis does not include disappearances and deaths from unknown causes. Mortality rates are adjusted for group size.

Another way to explore the risks encountered while raiding is the survivorship of infants born into each type of foraging strategy. Lifetables have been widely used to study survivorship in wild vertebrates (Caughley 1977) and nonhuman primates (Dunbar 1988; Fedigan and Zohar 1997). The cumulative probability of surviving to the oldest possible age during this study is the basis of the analysis. The KaplanMeier product limit method is preferred because it estimates the survivorship function directly from continuous survival times using each case, rather than accumulating cases according to predetermined intervals. Data are truncated to the oldest age theoretically possible within the study period (1155 d) because survivorship curves are sensitive to their end points. The program used Gehan's generalized Wilcoxon test and takes into account censored data (Statsoft 2005).

We recorded 762 injuries from PHG (1977-1984) and from WBY (1981-1984). We adjusted the injury rate for group size or cohort size within age-sex classes. This yielded a per capita rate for comparisons between troops and between and within age-sex classes (males: adult, subadult, juvenile, infant; females: adult, subadult, juvenile, infant). The result, average injury rate per individual or per age-sex class, is compared within and between troops.

We recorded home range every 15 min via a topographical map of Kenya (Survey of Kenya 1975) in which kilometer grid squares were further divided into 4 smaller units. The tabulated home ranges $\left(\mathrm{km}^{2}\right)$ during the study period also identify areas of highest density of human foods. We compare only matching time periods; in 1981 this was 6 mo (after troop fission) and in 1984 only 9 mo (before translocation).

Sleeping site data consist of the frequencies at each rocky cliff ledge referred to by the vernacular name for the site and its grid square reference point.

Baboon foraging strategies are divided into 2 broad categories assigned based on the fission of the Pumphouse group. I call the main troop, Pumphouse (PHG), nonraiders because they continued to feed primarily on natural forage and the splinter troop, Wabaya (WBY), raiders because they came to specialize on human food.

All analyses use CSS Statistica (Statsoft 2005). The large data sets of diet and activity budgets are examined using analysis of variance for main and interaction effects with Tukey HSD post hoc tests for significant differences between marginal means. Other analyses employ standard parametric and nonparametric tests. CSS 
assesses survival curves using 5 independent tests and then selects the one that has the best fit. Activity budgets and diets in the tables are in actual proportions instead of the arc sine transformed data used for the statistical analysis.

\section{Results}

\section{Human Food as Part of the Baboon Diet}

Nonraiders during this study ate the traditional baboon diet. The diet composition varied across ecological periods $(n=33,773$; 1 -way ANOVA, df=5, $F=64.83, p<$ $0.001 ; 6$ ecological periods; 4 quantitative food variables: human, grass, herbs, other). In 1981, the diet consisted primarily of grasses $(88.4 \%)$, some herbs $(4.6 \%)$, and a few other items (7.5\%) such as food from animals, bushes, and trees but not human food (Fig. 1).

The types of food in the nonraider diet often correlate with each other when examined in terms of a larger set of food categories (human food, animal food, grasses, herbs, bushes, trees, and miscellaneous food types: Table III). As expected, when grass biomass declined, as in low biomass periods, bushes and trees contributed more to the diet (grasses and trees $r=-0.54, p<0.05$; grasses and bushes $r=-0.85, p<0.05)$. Nonraiders tried human food but ate negligible amounts in all ecological periods but one. Human food made up $<0.02 \%$ in high biomass periods (1981; 1982 high; 1983 high) and 9.2\% in low biomass seasons (1982 low; 1983
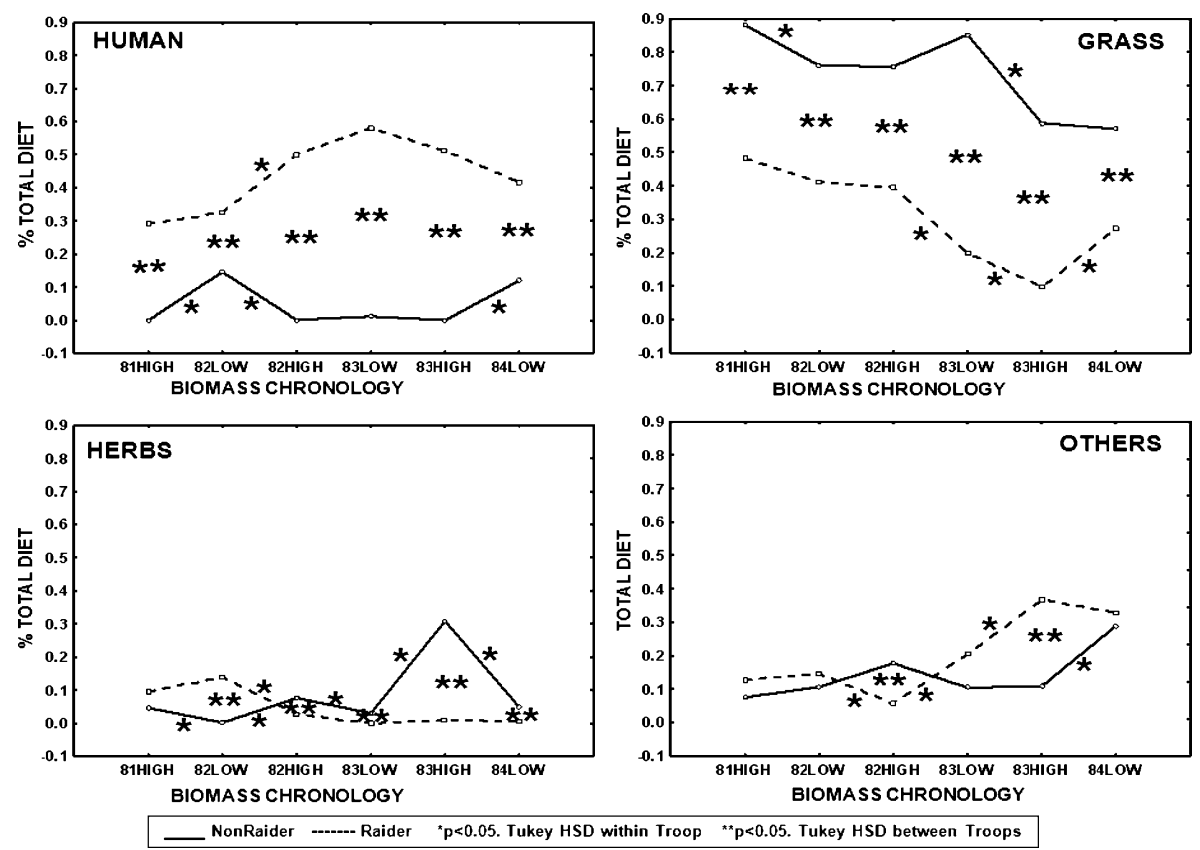

Fig. 1 Major food categories for raiders and nonraiders across seasons and years. *Intratroop comparisons: $p<0.05$, Tukey HSD test; **intertroop comparisons, Tukey HSD test. 


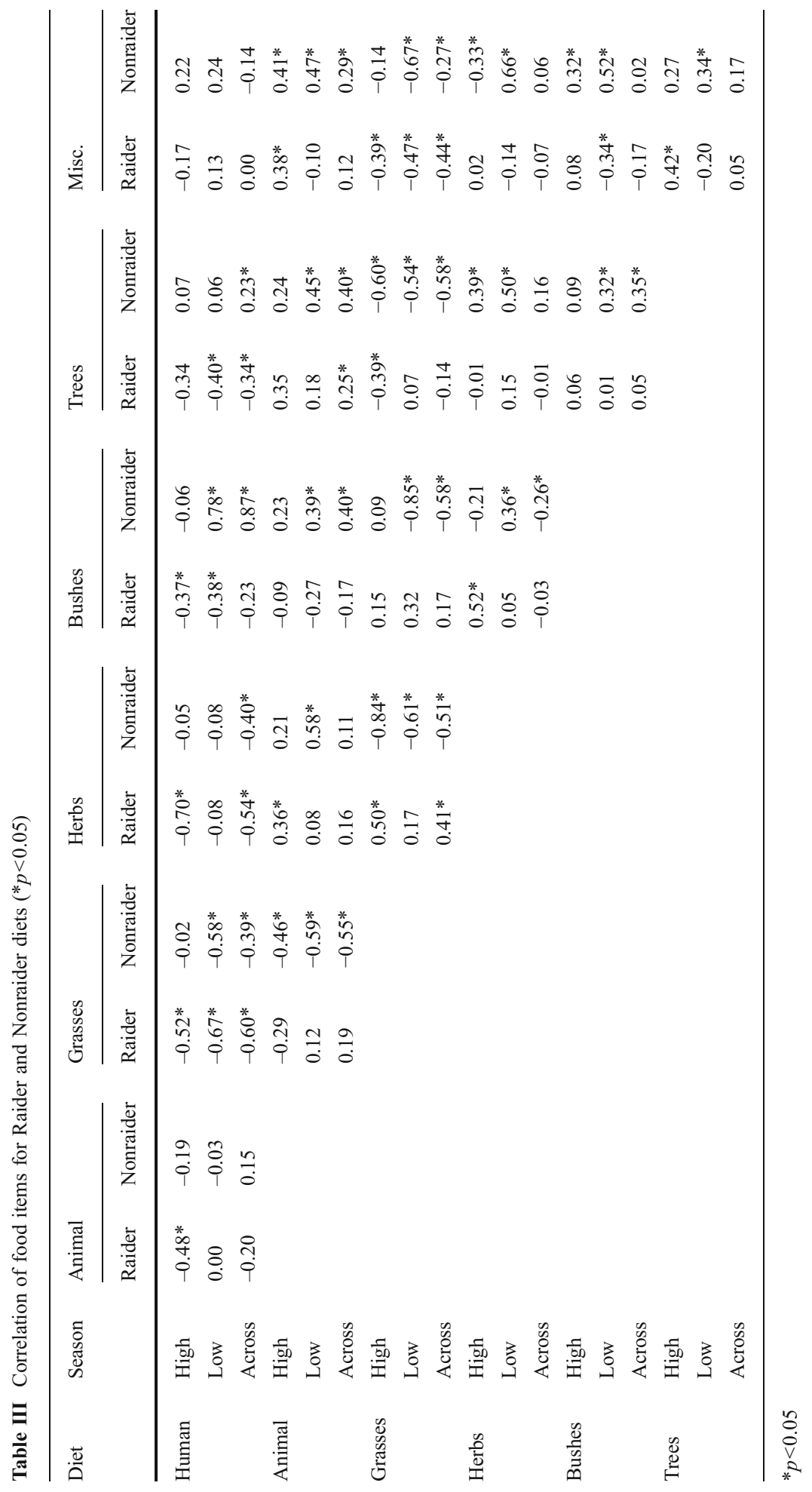


low; 1984). However, for a short time in 1982 human foods contributed $14.5 \%$ to the nonraider diet (Fig. 1).

By contrast, raiders gradually increased their consumption of human food from a low of $29.2 \%$ at the start of the study in 1981 (Fig. 1) to a peak of 58.\% in the 1983 low biomass period ( $n=7921$; 1 -way ANOVA, $\mathrm{df}=5, F=25.93, p<0.05$; Tukey HSD post hoc test: 1981 High vs. 1983 Low, $p=0.00 ; 6$ ecological periods; 4 quantitative food variables: human, grass, herbs, other). Human food remained between $40 \%$ and $50 \%$ of the diet subsequently. Initially human food consisted primarily of cultivated crops (maize, cabbage, beans, and potatoes) but later it included refuse in garbage pits. The addition of human food to the diet was correlated with a decline of other major foods (grasses $r=-0.60, p<0.05$; herbs $r=-0.54, p<0.05$; trees $r=-0.34, p<0.05$ ) but not bushes $(r=-0.23, p>0.05)$ or miscellaneous foods $(r=0.00, p>0.05$; Table III).

Raider diets diverged sharply from nonraider diets in all years and ecological periods because of the addition of human food (MANOVA, $n=41,694$; troop effect, $\mathrm{df}=1, F=528.63 ; p<0.001$; troop/period interaction effect, $\mathrm{df}=5, F=36.79 ; p<$ $0.001 ; 6$ ecological periods, 2 troops, 4 quantitative food variables: human, grass, herbs, other). Still, raiders did not completely switch to human food. They also ate natural foods, particularly grasses which was the major component of the nonraider diet but at a lower rate than nonraiders (Tukey post hoc test, $p<0.001$ for all comparisons). Even when the feeding budget converged again during the 1984 drought (Fig. 2), the 2 diets differed ( $n=5195$ for 1984 diet data, 1-way ANOVA, $\mathrm{df}=1 ; F=54.48, \quad p<0.001 ; 1$ ecological period; 2 troops; 4 quantitative food variables: human, grass, herbs, other). The raider diet had significantly more human food (41.6\% vs. $11.9 \%$, Tukey post hoc test $p<0.001)$, and less grass $(27.2 \%$ vs. $57.0 \%$, Tukey post hoc test $p<0.001)$ and herb foods $(0.5 \%$ vs. $4.9 \%$, Tukey post hoc test $p<0.001)$ than the nonraider drought diet. Raiders did not differ from nonraiders in the other foods that contributed to the diet $(32.7 \%$ vs. $28.0 \%$, Tukey post hoc test $p>0.05$ ). Thus raiders adjusted their diet during the drought. So did the nonraiders but the difference between them remained significant in 3 of the 4 major categories. Raiders, like nonraiders, had some dietary flexibility still.

\section{Impact of Change in Diet on Activity Budgets}

A major change in diet should have consequences for activity budgets. This is apparent when nonraiders and raiders are examined chronologically across activities (Table IV; $n=131,508$; MANOVA, troop effect: $\mathrm{df}=1, F=205.2, p<0.001$; troop/ period interaction effect: $\mathrm{df}=520, F=17.7, p<0.001 ; 2$ troops, 6 ecological periods, 4 quantitative activities: feeding, traveling, resting, social). Raiders feed less than nonraiders in both high and low biomass conditions (MANOVA, df $=1, F=168.9$, $p<0.001$; Tukey post hoc test; high biomass, $p<0.001$; low biomass, $p<0.001 ; 2$ troops, 6 ecological periods, 4 quantitative activities: feeding, traveling, resting, social). They also feed less than nonraiders in every ecological period except the 1984 drought (raider vs. nonraider Tukey post hoc test, $p=0.00$ for every comparison except 1984: raider $=38.1 \%$, nonraider $=41.7 \%$, Tukey post hoc test, $p>0.05$; Fig. 2). Raider feeding ranged from a low of $24.1 \%$ to a high of $38.1 \%$ while nonraiders feeding ranged from a low of $38.0 \%$ to a high of $61.3 \%$ of their activity budget. 

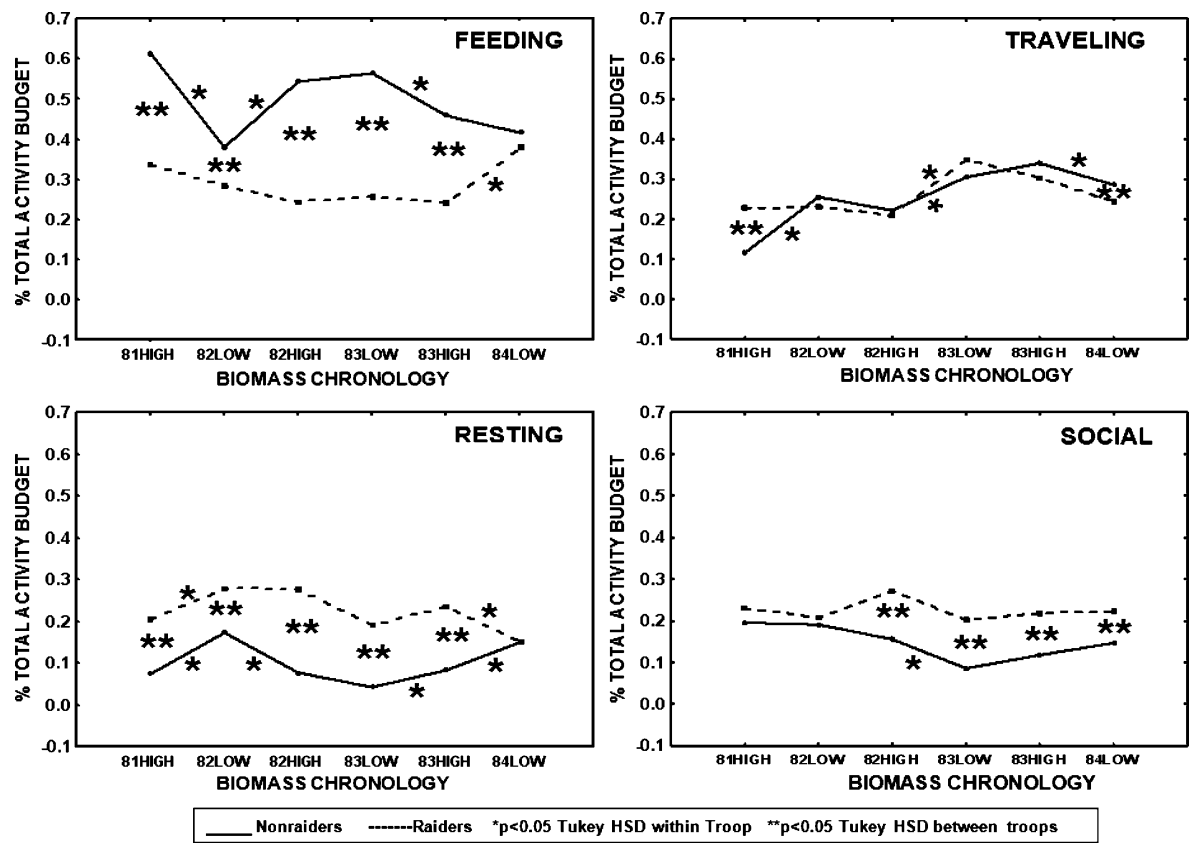

Fig. 2 Basic activities in raider and nonraider budgets across seasons and years. *Intratroop comparisons: $p<0.05$, Tukey HSD test; **intertroop comparisons, Tukey HSD test.

Feeding was inversely related to resting in both biomass conditions for raider (high: $r=-0.61, p<0.05$; low: $r=-0.55, p<0.05$ ) and nonraider (high: $-0.59, p<$ 0.05 ; low: $r=-0.53, p<0.05$ ) activity budgets (Table V). The difference is in the relative proportion devoted to each activity. Raiders fed less and rested more than nonraiders. In 1981 nonraiders rested for $7.6 \%$ of their budget whereas raiders rested for $20.6 \%$ (Tukey post hoc test, $p<0.001$ ). This difference in resting continued until the drought in 1984 (Fig. 2). For example, in both the low and high biomass seasons

Table IV Activity budgets of Raiders and Nonraiders during the different ecological periods $\left({ }^{*} p<0.05\right.$, Tukey HSD test)

\begin{tabular}{|c|c|c|c|c|c|c|c|c|}
\hline \multirow{3}{*}{$\begin{array}{l}\text { Percentage of } \\
\text { budget }\end{array}$} & \multicolumn{8}{|c|}{ Type of activity } \\
\hline & \multicolumn{2}{|l|}{ Feeding } & \multicolumn{2}{|l|}{ Travel } & \multicolumn{2}{|l|}{ Resting } & \multicolumn{2}{|l|}{ Social } \\
\hline & Raiders & Nonraiders & Raiders & Nonraiders & Raiders & Nonraiders & Raiders & Nonraiders \\
\hline 1981 High & $33.68^{*}$ & 61.29 & $22.68^{*}$ & 11.54 & $20.64 *$ & 7.58 & 23.00 & 19.59 \\
\hline 1982 Low & $28.33^{*}$ & 37.98 & 23.19 & 25.53 & $27.83 *$ & 17.40 & 20.65 & 19.09 \\
\hline 1982 High & $24.31^{*}$ & 54.50 & 20.85 & 22.13 & $27.73 *$ & 7.82 & $27.12 *$ & 15.56 \\
\hline 1983 Low & $25.86^{*}$ & 56.57 & 34.70 & 30.49 & $19.18 *$ & 4.37 & $20.26^{*}$ & 8.58 \\
\hline 1983 High & $24.12^{*}$ & 45.93 & 30.35 & 33.89 & $23.61 *$ & 8.43 & $21.92 *$ & 11.76 \\
\hline 1984 Low & 38.12 & 41.66 & $24.41 *$ & 28.63 & 15.10 & 15.03 & $22.37 *$ & 14.69 \\
\hline
\end{tabular}

Tukey HSD Test of marginal means, ${ }^{*} p<0.05$ 
Table V Correlation of activities within the activity budgets of Raiders and Nonraiders during high and low biomass seasons and overall $(* p<0.05)$

\begin{tabular}{|c|c|c|c|c|c|c|c|}
\hline \multirow[t]{2}{*}{ Activity } & \multirow[t]{2}{*}{ Season } & \multicolumn{2}{|l|}{ Travel } & \multicolumn{2}{|l|}{ Resting } & \multicolumn{2}{|l|}{ Social } \\
\hline & & Raider & Nonraider & Raider & Nonraider & Raider & Nonraider \\
\hline \multirow[t]{2}{*}{ Feeding } & High & $-0.60^{*}$ & $-0.88^{*}$ & $-0.61^{*}$ & $-0.59^{*}$ & -0.20 & $0.76^{*}$ \\
\hline & Low & $-0.53^{*}$ & -0.51 & $-0.55^{*}$ & $-0.53^{*}$ & $0.38^{*}$ & 0.27 \\
\hline \multirow[t]{2}{*}{ Travel } & High & & & 0.01 & 0.21 & -0.06 & $-0.81^{*}$ \\
\hline & Low & & & $-0.35^{*}$ & -0.36 & 0.002 & $-0.71^{*}$ \\
\hline \multirow[t]{2}{*}{ Resting } & High & & & & & $-0.33 *$ & $-0.48^{*}$ \\
\hline & Low & & & & & $-0.64 *$ & 0.10 \\
\hline
\end{tabular}

in 1982, raiders rested for $28 \%$ of their budget while nonraiders resting declined from $17.4 \%$ to $7.8 \%$ (Tukey post hoc test, $p<0.001$ for both seasons). This difference disappeared in the drought (raider resting $15.1 \%$ vs. nonraider resting $15 \%$; Tukey post hoc test $p>0.05$ ) when raiders took time from resting to feed.

Raider feeding and socializing correlate positively in the low season $(r=0.38, p<$ 0.05 ) whereas nonraider feeding and socializing correlate positively in the high biomass seasons $(r=0.76, p<0.05)$. At the early stage of raiding, raider and nonraider social investment was the same (23\% vs. $19.6 \%$; Tukey post hoc test; $p>$ $0.05)$. By late 1982 nonraiders social activity declined whereas raider socializing increased $(27.1 \%$ vs. $15.6 \%$; Tukey post hoc test $p<0.001)$. After that, raiders managed to sustain the high biomass socializing regardless of ecological conditions. Nonraider socializing remained low (as low as 8.6\%) for the rest of the study. The socializing differences could not be the result of differences in group size because the per capita socializing rate indicated that raiders remained more socially active than nonraiders, even in the drought (Wilcoxon matched pairs test: $n=16, T=9.00$, $Z=3.05, p<0.002$ ).

Traveling and feeding were negatively correlated for raiders and nonraiders during both high and low biomass conditions (high biomass raider: $r=-0.60, p<$ 0.05 ; nonraider: $r=-0.88, p<0.05$; low biomass raider $r=-0.53, p<0.05$; nonraider: $r=-0.51, p<0.05)$. Raiders traveled more than nonraiders at the start of the study (raiders $22.7 \%$ vs. nonraiders $11.5 \%$; Tukey post hoc test, $p<0.001$; Table IV). There was no significant difference again until 1984, when raiders traveled less than nonraiders (raiders $24.4 \%$ vs. nonraiders $28.6 \%$; Tukey post hoc test $p=0.03$ ).

\section{Diet and Home Range Use}

Home range use changed along with the diet. This included a change in the size of the home range, in the preference for specific locations within the home range, and in the use of sleeping sites. Nonraider home range varied from $13 \mathrm{~km}^{2}$ in 1981 to a high of $21.5 \mathrm{~km}^{2}$ in 1984 . By contrast, the raider troop home range was small from the start and stayed small. It was only $4.5 \mathrm{~km}^{2}$ in 1981 (6 mo total) and $8.75 \mathrm{~km}^{2}$ at its largest in 1983. Raider and nonraider home ranges were significantly different for 
each year of the study (Wilcoxon matched pairs test: 1981, $n=6, T=1.00, z=1.99$, $p=0.05 ; 1982, n=11, T=1.00, z=2.85, p=0.00 ; 1983, n=12, T=0.00, z=3.06, p=$ $0.00 ; 1984, n=8, T=0.00, z=2.52, p=0.01)$.

The focus of nonraider activity also shifted to the area of highest density of human food, about $3 \mathrm{~km}^{2}$. This represented $14-23 \%$ of the nonraider's and $34-67 \%$ of the raiders' home range depending on the year. Nonraiders spent $10 \%$ of their time in that area but only $2.3 \%$ after the troop split in 1981. Raiders spent significantly more of their time there once the raiding troop became viable, in July 1981 (Wilcoxon matched pairs test: $n=6, T=0.00, z=2.02, p=0.04$ ). Subsequently, raiders continued to prefer this area $(89 \%$ in 1982 and $1982 ; 97 \%$ in 1984). Nonraiders used the area significantly less than raiders in all years (Wilcoxon matched pairs test: 1982, $n=11, T=0.00, z=2.93, p=00 ; 1983, n=12, T=0.00, z=$ $3.06, p=0.00 ; 1984, n=8, T=0.00, z=2.52, p=0.01)$. Nonraiders focused primarily on natural foods while raiders ate human foods (Fig. 1).

Raiders changed their sleeping sites as well. Both troops slept near each other at the start of the study. This included 5 of the 7 sleeping sites located on 2 granite cliffs that bisected their home range. Later, raiders slept at the sites closest to where they found human food. Ultimately they slept at the site in closest proximity to human food $98 \%$ of the time. By contrast, the nonraider troop continued to sleep at a variety of places (11 different sites in 1984) throughout their home ranges.

\section{Female Reproduction}

The mean raider female IBI was $433 \mathrm{~d}$ ( $n=28$ births). During the same period the mean nonraider IBI was $645 \mathrm{~d}(n=28$ births), a significant difference $(t=6.15, \mathrm{df}=$ $26, p<0.00)$. In addition, 6 of 14 raider female interbirth intervals were shorter than the average length for raiders, ranging between 369 and $394 \mathrm{~d}$. The mean raider female interbirth interval was significantly less than the mean for the troop from which it came. Pumphouse IBI was calculated for the preceding $4 \mathrm{yr}$, the time before human settlement (33 intervals for PHG; 14 intervals WBY $t=3.44 ; \mathrm{df}=45 ; p<0.00$ ). It is not possible to compare reproductive females of all ages $(5.5 \mathrm{yr}$ to $>20 \mathrm{yr}$; Strum and Western 1982). The raider group had primarily younger females ages 5.5$12 \mathrm{yr}$ (age classes 1 and 2) and 1 old female $>20 \mathrm{yr}$ of age (age class 5). However, comparisons within age class are suggestive. Raider young multiparous females (age class $2 ; 8-12$ yr of age) had a significantly lower IBI during the study than nonraiders of the same age classes $\left(n_{1}=6, n_{2}=11, t=4.97, p<0.00\right)$ and also a shorter IBI than same-age females during the $4 \mathrm{yr}$ preceding fission $\left(n_{1}=12, n_{2}=11, \mathrm{df}=21\right.$, $t=3.75, p<0.00$ ). The youngest raider females (age class $1 ; 5.5-8 \mathrm{yr}$ ) had a mean IBI of $473 \mathrm{~d}(n=2)$. This was shorter than the only nonraider IBI $(586 \mathrm{~d})$. The mean for the larger pre-settlement sample was $840 \mathrm{~d}$ (Strum and Western 1982). There were no raider females between 12 and $20 \mathrm{yr}$ old (age class 3 and 4). The IBI of the 1 old raider female declined as she moved from nonraider to raider (602 vs. $464 \mathrm{~d}$ ), which contradicted predictions from the age-specific fecundity curve (Strum and Western 1982). Her IBI was also less than the mean IBI for nonraider females in this oldest class calculated for the earlier period (656 d; Strum and Western 1982). There were 6 raider females that had 2 interbirth intervals while in the same class. In every case, the second IBI was shorter than the first $(n=6, x=0$, binomial test, $p=0.016)$. By 
contrast, no nonraider female had 2 interbirth intervals while in the same age class. In the 4 yr preceding this study, the naturally foraging troop had 12 cases of females that remained in the same age class or made a transition to an age class that should have a lower IBI based on this population's fecundity curve (Strum and Western 1982). All 12 showed the opposite trend. Their second IBI was longer instead of shorter than their first IBI $(n=12, x=0$, binomial, $p<0.00)$.

The decline in age at first reproduction from January 1981 through April 1984 (raider: $n=6, r^{2}=0.59, p=0.08$; nonraider: $n=13, r^{2}=0.54, p=0.00$; Fig. 3 a) is likely the result of the high biomass period during 1978-1979. The raider and nonraider regression lines are similar $(t=0.168, p=0.87)$. The mean age at first reproduction for the 2 foraging strategies is not different $(t=1386, \mathrm{df}=17, p=0.18)$. There are only 3 females, 1 raider and 2 nonraiders, whose growth occurred largely during this study. These females were born in 1977 and had their first births at the end of the raiding study. The raider case falls near the mean for the nonraiders.

Keeping in mind that translocation might influence a female's life history, I added data for 9 females, 6 nonraiders and 3 raiders, that were born during the raiding period but had their first infant after translocation between 1985 and 1990 (Fig. 3b). The best fit for nonraider females from 1981 to 1990 is a polynomial that shows an increasing age at first birth $\left(n=19, R^{2}=0.25, p=0.08\right)$. The best fit for raider females shows a decline age at first birth during the same period $\left(n=9, R^{2}=-0.42, p=0.06\right)$. Raider females were younger at first birth in every case compared to any nonraider females in the sample (raider mean $=2310$; nonraider mean $=2795 ; \mathrm{df}=8, t=27.54$, $p<0.00$ ). This suggests that the biomass bonus of 1978-1979 added to the energetic savings of raiding continued to decrease age at first reproduction for previously raider females but not for those that had not raided.

\section{Survivorship, Injuries, and Mortality: Potential Costs}

Nonraiders did not have a higher per capita injury rate because of agricultural settlement comparing the $4 \mathrm{yr}$ before (mean of 1.78) and the $4 \mathrm{yr}$ after (mean of 1.05) human settlement (Wilcoxon matched pairs test, $n=4, T=3.00, z=0.73, p=$ 0.47). However, the trend was that anthropogenic injuries increased with settlement (1973-1981 vs. $1981-1984 ; t=1.93, \mathrm{df}=10, p=0.08)$ from a mean of 0.01 to a mean of 0.05 per individual for the nonraider troop. The per capita anthropogenic injury rate rose to 0.13 in 1982 , but raiders did not have more injuries than nonraiders (Wilcoxon matched pairs test, $n=4, T=2.00, z=1.10, p=0.27$ ). In fact, raider adult and subadult males had lower injury rates than their nonraider counterparts (mean of 1.91 vs. 2.61 for nonraiders) but not significantly so (Wilcoxon matched pairs test; $n=4, T=3.00, z=0.73, p=0.47)$. Raider adult and subadult females also had a trend towards fewer injuries (raider mean 0.69 vs. nonraider mean 1.24; Wilcoxon matched pairs test; $n=4, T=0.00, z=1.83, p=0.07)$. Therefore, based on the risk of injury, raiding does not seem to be more dangerous.

However, there was a large shift in the source of mortality and the per capita annual rate of mortality during the period of agricultural settlement (1979-1984). Human-related deaths increased for nonraiders from 5.35 per capita in 1981 to 9.69 in 1984 (nonraider; $n_{1,2}=6, t=3.83, \mathrm{df}=10, p=0.00$ ). Raider and nonraider per capita mortality rates from human causes did not differ (Wilcoxon matched pairs test, $n=4$, 

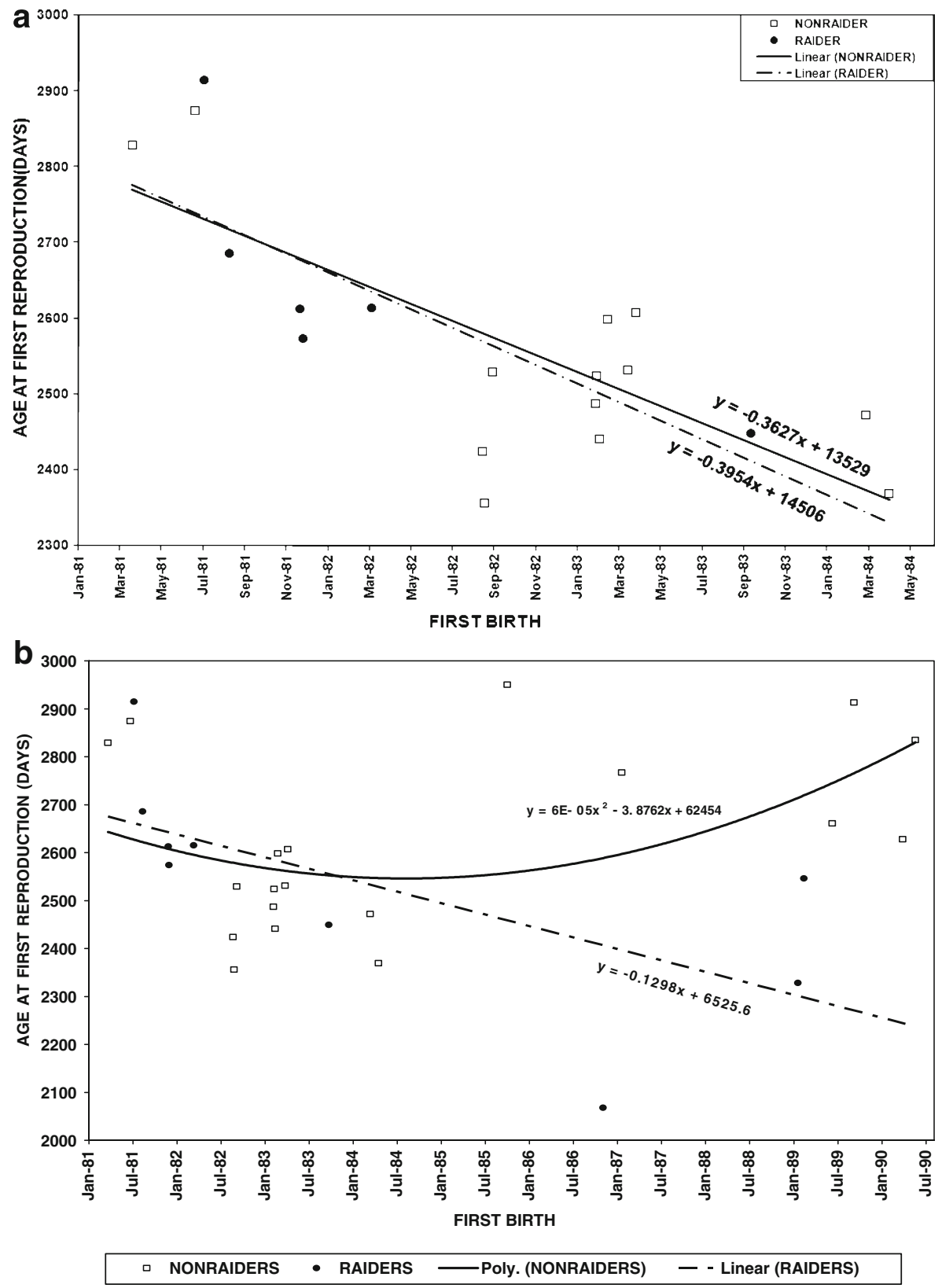

Fig. 3 (a) Best fit lines for age at first reproduction for raider and nonraider females across the study period (b) Best fit lines for age at first reproduction for raider and nonraider females including infants born after study period. Best fit to raider data is linear $(y=-0.1298 x=6525.6)$; best first to nonraider data is curvilinear $\left(y=6 \mathrm{E}-05 x^{2}-3,8762 x+6245\right)$. 
$T=4.00, z=0.365, p=0.72)$. The trend was that raiders (mean per capita of 0.75$)$ died less than nonraiders (mean per capita 3.71) from natural causes (Wilcoxon matched pairs test, $n=4, T=0.00, z=1.83, p=0.07$ ). Annual mortality rate increased (Fig. 4). The rate for the nonraider troops rose steadily (the peak in 1979 represented the nonraider troop's first encounters with farmers). The story is more complicated for raiders. Naïve raiders had no mortality in 1981 but as the raiding developed, the death rate rose and then fell dramatically. Raider mortality dropped below nonraiders in 1983 (nonraiders $=10.23$, raiders $=3.45$ ) and 1984 (nonraiders $=14.54$, raiders $=$ 11.94). When averaged over the period, raider and nonraider rates are not different $\left(n_{1,2}=4, t=-0.62, \mathrm{df}=6, p=0.56\right)$. Raiders, more than nonraiders, appeared to make adjustments to the new sources of risk.

Raider infants survived just as well as nonraider infants. The two survival curves are not significantly different $(n=19, z=-0.21, p=0.83)$. At the end of the study the cumulative proportion surviving in the last interval was 0.023 for raiders and 0.027 for nonraider infants.

\section{Discussion}

What does it means for primates to invade the human realm? Primate studies inherited a scientific framework that divided time and space into natural and unnatural (Oelschlaeger 1991; Primack 2006; Thomas 1983) and identified the proper site of research to be places devoid of humans (Strum and Fedigan 2000). I have argued that from the baboons' point of view, this is a false dichotomy (Strum 1987; Strum and Western 1982). Today, with escalating human-wildlife conflict the dichotomy obscures a major shift in primate selection pressures. This research

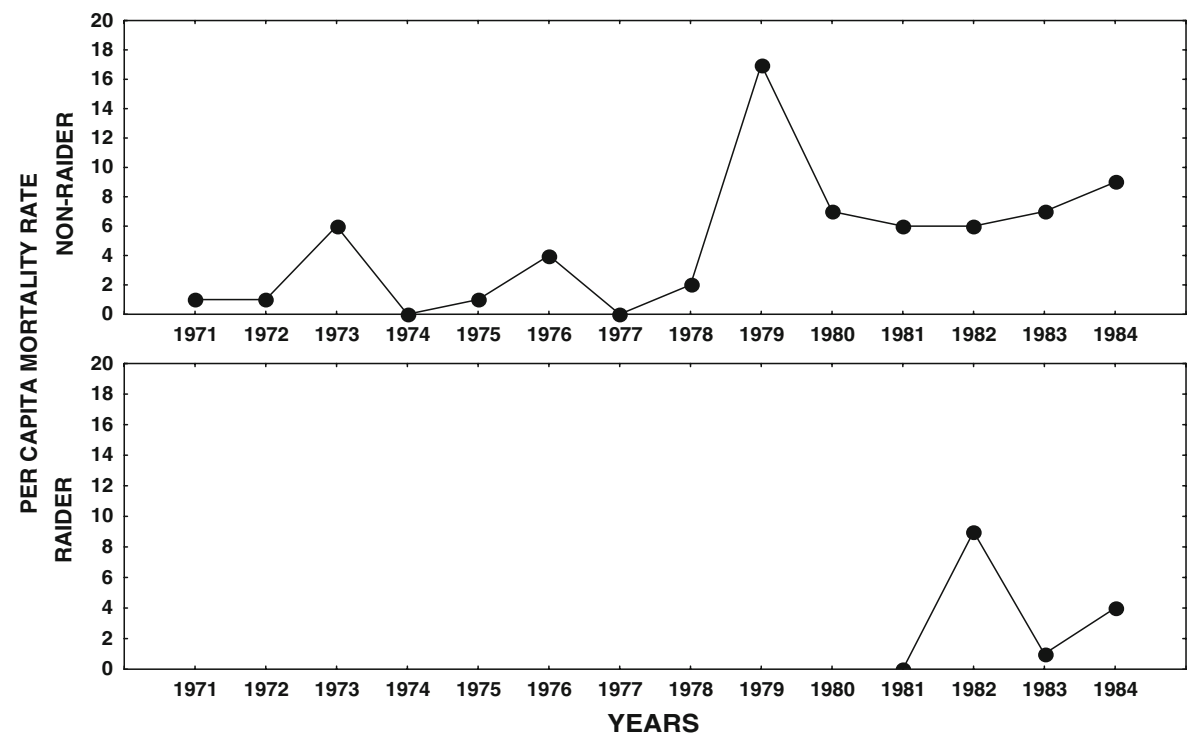

Fig. 4 Per capita mortality rate for raider and nonraider troops (1971-1984). Note: The raider troop originated in July, 1981 as a splinter from the nonraider troop. 
illustrates the value of scientific study for understanding how and why baboons utilize new, human, resources. First, it provides evidence that raiding not only alters activity budgets but also reproduction which depends on growth rates (see also Altmann and Alberts 1987; Altmann et al. 1993). Second, the study demonstrates that baboon responses to human activity are more complex than predicted from studies of established raiders. Missing from these is the development of a raiding lifestyle. The tendency to raid in this study varied between troops and within troops. I look at raiding as a foraging strategy and the variation in raiding tendencies to discuss existing control techniques and to provide a framework that might generate more effective management methods.

\section{Why Raid?}

At the most basic level, raiders targeted human foods because these have nutritional advantages over natural forage. Forthman-Quick and Demment (1988, see Table 7) report data from the same field site illustrating that human foods were higher in carbohydrates and calories and lower in fiber than natural foods. They were easier to process and to digest. Human foods are also generally larger (ForthmanQuick and Demment 1988). Natural forage did, however, contain higher proportions of protein. Raiders got more energy for less effort when they ate human food. For example, corms (of sedges) were a major natural food in the nonraider diet. Yet corms yielded only $1.2 \mathrm{~g} / \mathrm{min}$ harvest compared with $20-50 \mathrm{~g} / \mathrm{min}$ potato harvest (see Table 7 in Forthman-Quick and Demment 1988). Raiders therefore gain a significant energy bonus eating human foods (see Altmann and Alberts 1987; Altmann and Muruthi 1988; Altmann et al. 1993; Biquand et al. 1994; Bourg et al. 1994; Bronikowski and Altmann 1996; Forthman 1986a, b; Hill 2000; Kemnitz et al. 2002; Naughton-Treves 1998; Naughton-Treves et al. 1998; Tarara et al. 1985; Warren et al. 2007).

The energy bonus and time savings of Wabaya raiders translated into more time for resting and socializing. This powerful linkage between food quality and quantity and activity budgets has also been reported from other studies of food enhanced baboons that have data on foraging strategies (Altmann et al. 1993; Altmann and Muruthi 1988; Forthman 1986a, b; Forthman-Quick and Demment 1988; Muruthi et al. 1991). The improvement in diet and decrease in foraging time is reflected in growth and reproduction (Altmann and Alberts 1987; Altmann et al. 1993; Barrett and Henzi 1997). Wabaya raider males and females grew faster, reached asymptotic weight earlier, and achieved heavier final weights (Strum 1991). The current analysis shows that raider females reproduced faster and had shorter interbirth intervals and earlier first reproduction. The benefits of raiding for males are more difficult to quantify. Still, a raider male that weighed more than nonraiders would have a competitive aggressive advantage if he transferred to a nonraider group (Strum 1993).

Other studies have speculated that raiding comes with heightened costs such as injuries from competition over human food and disease transmission from humans (Altmann and Muruthi 1988; Forthman-Quick and Demment 1988). However, only Sapolsky and colleagues (Tarara et al. 1985) document raiding costs. They showed that raiders in the Masai Mara, Kenya suffered high mortality from tuberculosis when they ate contaminated meat at lodge refuse pits. Kekopey raiders also 
experienced costs. Deaths from human conflict rose. However, raiders didn't have more injuries than nonraiders and the survival rates of infants from both foraging strategies were indistinguishable. On balance then, the transition to a raiding lifestyle in this population provided more benefits than costs.

\section{Variation in Raiding Tendencies}

This study demonstrates that in order to exploit new human resources, naïve baboons make complex modifications in behavior; these vary between troops and take time to learn and develop effectively. Despite improved growth and reproductive rates, not all naïve baboons chose to raid. Pumphouse (PHG) split into two groups, one raiding, the others not. The raider group contained only young adult and subadult males that were already leaving the troop to raid and young adult or subadult females. The females were the oldest daughters in their matriline, but most oldest daughters remained in Pumphouse. One crucial factor appeared to be these females' strong social ties to the raiding males (Smuts 1985; Strum 1987). The exception to this rule was an older female, the lowest ranking in PHG, which joined Wabaya bringing her adolescent daughter with her. Neither female had ties to the raider males. They moved back and forth for several months before staying with the raider group. While they remained the lowest ranking females, they benefited nutritionally from raiding and had fewer females to compete with. A few animals in another study group, Eburru Cliffs (EC; Smuts 1985; Smuts and Nicholson 1989) also experimented with raiding when cultivation began. They suffered heightened mortality and subsequently abandoned the settled area, ranging as far away as they could from the farms and stay within their traditional home range.

These case histories show that raiding is not inevitable at the start. Group dynamics molded the decision to raid but opportunities to raid also influenced individual behavior which had ramifications for group dynamics. The transition to raiding took time. Pumphouse individuals had extensive and intensive negotiations over whether to raid even after the fission was complete. Raiders face considerable challenges. They must overcome fear of people, avoid injury, and learn foraging strategies in the new context. They must also adjust ranging patterns and sleeping sites. Over time, Wabaya raiders were able to increase their raiding success and reduce the potentially high cost of being close to people.

Baboon behavior responded to variations in ecological conditions. For example, raiders and nonraiders had similar levels of resting and socializing when food was plentiful in 1981. Subsequently raiders maintained a high level of socializing despite seasonal fluctuations in natural foods. Raider and nonraider activity budgets converged once again at the end of the study during the drought in 1984. Raiders, forced to look for natural foods in addition to human foods, spent as much time feeding as nonraiders. Longer foraging time decreased raider resting time. Nonraiders increased resting as they decreased feeding because there was so little natural forage.

\section{Implications for Primate Management (and Conservation)}

Primates are the most challenging of all the larger mammals to control because they are so intelligent (Conover 2002; Woodroffe et al. 2005). Baboons are among the 
hardiest of primate pests because they are so adaptable. This study is useful for understanding why control techniques succeed or fail. It is also highlights the basic requirements of new control methods for baboon raiders.

\section{Why Techniques Succeed or Fail}

Treating raiding as a foraging strategy makes it possible to understand the conditions under which traditional control techniques, like guarding and chasing, succeed and fail (see Osborn and Hill 2005). Deterrence, if it is to work, must increase the costs of raiding and decrease net reproduction compared to natural foraging. Because raiders save foraging time, they can "sit and wait." Raiders can meet their daily needs with only a short break in guarding because of the net energy bonus of most human foods. Spurts of chasing baboons are ineffective. Raiders simply play hide and seek with the chasers and bide their time. However, chasing as a control technique improves with rising threats or with continuous guarding. Who chases and how they chase also matters. Baboons are more afraid of men than of women, of women than children (pers. obs and Kansky 2002). But being energetic rather than lackadaisical improves anyone's success, a fact that many farmers in Africa already know. Chasing baboons/primates with a pack of dogs or with a weapon or throwing stones also heightens the perception of risk and improves success. Killing a raider (by shooting or other means) is the ultimate escalation of risk. Although I did not advocate shooting as a control method, several baboons were shot or killed as a result of raiding. Shooting is effective only if the animal is killed in full view of the group caught in the act of raiding. Otherwise, the connection between action and consequence, benefit and cost, is not learned by the rest of the troop. Male baboons, in particular, often emigrate from the group so a male's disappearance is unremarkable. Whether killing a few raiders is an effective long-term strategy has yet to be demonstrated (Treves and Naughton-Treves 2005).

Although traditional techniques can work, they may no longer be realistic because guarding and chasing are time and labor intensive. Those who previously guarded consistently are now often not around: children go to school and many adults are employed elsewhere. However, paid "baboon monitors" are employed to protect residential housing estates from baboon raiders in the Cape, South Africa (Kansky 2002), a modern variant of the traditional approach. A further obstacle to effective deterrence is the shift in notions of responsibility in civil society as traditional societies disappear. Property owners now tend to hold "someone else," usually governments, NGOs and researchers, responsible for loss of their crops, livestock or damage to homesteads (see also Naughton-Treves and Treves 2005).

I briefly tried other, less traditional, control methods including loud thunderflashers, alarm vocalization playbacks and leopard dung (Strum 1987). None increased the perceived risk enough to be effective. Conditioned taste aversion (CTA) was a more promising approach. CTA raises the costs by manipulating a basic mammalian physiological response; however, baboons could taste lithium chloride when it was used as an emetic in doses high enough to produce vomiting (Forthman 1986a; Forthman et al. 2005). CTA for primates needs an emetic which is tasteless to the primate palate and inexpensive to be effective on a large scale. 
By far the most effective approach to the conflict generated by baboon raiders was engaging the community (Community Based Conservation; Western et al. 1994). Working with people increased their awareness, improved their existing control strategies, and provided some benefits (in social services and by diversifying their livelihoods) to offset their costs. Larger political forces at my site intervened in the successful community based efforts. Translocation was then an effective but costly solution to human-baboon conflict (Strum 2005).

\section{Requirements for More Effective Control}

The challenge in conflict mitigation is to understand the crop-raiding behavior (see Conover 2002, for a general discussion for nonprimate vertebrates) and find better ways to manipulate the costs and benefits of raiding, for example, by using up time, increasing risks, or decreasing benefits. The current study demonstrates that not all members of a group or groups in a population will have the same proclivities to raid. Since raiding is not inevitable and there is a degree of flexibility in the early stages, recent raiders should be easier to control than long-term raiders. Greater effort should therefore be directed toward stopping raiding before the animals taste human food. While Wabaya raiders were still flexible and responsive to changes in their environment after 4 years, we do not know how long this flexibility lasts (and to what extent human food may gain a disproportionate attraction either through taste or tradition). Preventing raiding, however, depends on access to sufficient natural foods and on the exact location. Wabaya raiders adjusted their sleeping sites and ranging as raiding developed. This suggests that there might be strategic locations for intervention. Since individuals and age-sex classes have different raiding tendencies, it makes sense to identify and target the motivated "raiders." In the baboon case, these raiders were initially the young males. Attention should be devoted to the main raiders because controlling them or will have a bigger impact than trying to control the entire group.

Finally, methods of control should also consider the human context, past, present, and future. Changing crop varieties may help (Conover 2002). I did not systematically quantify crop damage as in recent studies of primate raiders (Hill 1997, 2000; Naughton-Treves 1998; Hill 2000; Warren et al. 2007) but plots with small items like leguminous beans appeared to be less attractive to the baboons than fields with larger items like maize and potatoes. This makes sense in terms of the relative time and energy of raiding compared to natural foraging.

\section{Developing a Rapid Assessment}

Control techniques have to manipulate costs and benefits by using up time, increasing risks or decreasing benefits sufficiently to push raiders back to natural foraging. Yet there may be situations in which primate raiders simply cannot be controlled. A rapid field assessment tool would be useful. Even without longterm data, it is possible to evaluate conflict with facts that can be collected quickly. This information should include the raiders' past history, their current ecological options, and the human context. Classifying raiders into three basic 
categories (traditional raiders, naïve newcomers, and those in between) helps identify appropriate management approaches and the probability of success.

- The history of raiding: How did it start? How did it spread? What were past control methods? Were they successful? $\rightarrow$ Assign raiders to a category.

- The current benefits and costs of raiding to primate raiders: What control techniques are now being used? Are they successful? Is the raider population increasing or decreasing? What are the injury and mortality rates? Who sustains the costs of raiding? $\rightarrow$ Assign a rough measure of the current benefit to cost ratio for the raiders.

- The ecological options: What is the ecological context? Do raiders have alternative natural foods? Where are these refuges located relative to sleeping sites, travel routes and areas of human settlement? Is raiding a life or death decision or a preference? $\rightarrow$ Assign degree of flexibility of the raiding foraging strategy.

- The human context: Whose property is being raided? What are the claims of damage? Whose responsibility is it to protect this property? What traditional or new policies or institutions are relevant to conflict mitigation? How are demographic and land use patterns changing in a way that influences protection of property? $\rightarrow$ Evaluate how to engage the victims.

Triage is useful. Long-standing raiders are difficult if not impossible to dissuade for reasons both of history and context. Removal of raiders or changing the benefits for the local community/residents to offset some of the costs may be the only options. By contrast, interventions with new raiders using traditional techniques or with new methods may be successful. What to do with those who fall in-between depends on the specifics: who, where, when, and the historical and ecological context. Of course, the best defense is an offense: stop primates from raiding before they start.

\section{Primate Conservation}

The recent rapid escalation of human-wildlife conflict involving primates reflects today's realities: previous primate habitat has suddenly turned into human dominated habitat (Cowlishaw and Dunbar 2000; Paterson and Wallis 2005). Primates besides baboons also target human foods making conflict a major threat to the survival of groups in a growing number of primate populations (see, e.g., Baker and Schutt 2005; Boulton et al. 1995, 1996; Chakravarthy and Thyagaraj 2005; Fa and Southwick 1988; Fitzgibbon et al. 1995; Fuentes and Wolfe 2002; Horrocks and Baulu 1988; Lee et al. 1986; Malik and Johnson 1994; Naughton-Treves 1998; Naughton-Treves et al. 1998; Onderdonk and Chapman 2000; Paterson 2005b; Saj et al. 1999a, b, 2001; Siex 2005; Sprague 2002; Warren et al. 2007). The factors generating conflict, human population growth, conversion of wild lands to agriculture, compression of existing primate populations, and primates adapting to a new foraging context, will continue to play a role in the future of primates.

I am pessimistic about our ability to halt primate conflicts over human resources but understanding raiding from both the nonhuman and the human point of view should make us more effective. The challenge for the next generation of scientists and conservationists is to develop better techniques and to learn how tailor solutions to specific circumstances. This might diminish the negative impact that primate 
raiders have on people's general attitudes towards conservation (Forthman et al. 2005; Naughton-Treves 1998; Naughton-Treves et al. 1998; Paterson 2005b).

Acknowledgments Many individuals contributed to the project data used in this analysis. I particularly thank Josiah Musau and Hudson Oyaro (Gilgil Baboon Project). David Muiruri, George Kebanya, and Steve Mutunga (Uaso Ngiro Baboon Project, UNBP) were indispensable during the data analysis. David Western, Debra Forthman, and Deborah Manzolillo Nightingale and 2 anonymous reviewers provided helpful comments on previous drafts. The research was sponsored by the Institute of Primate Research under the National Museums of Kenya and was funded by grants from the University of California, San Diego, Academic Senate, 1980-1981; the Fyssen Foundation, 1981; the East African Wildlife Society, 1981-1982; the New York Zoological Society, 1981-1983; the World Wildlife Fund, 1981, 1983; the L. S. B. Leakey Foundation, 1981, 1983; and the H. F. Guggenheim Foundation, 1983-1984.

Open Access This article is distributed under the terms of the Creative Commons Attribution Noncommercial License which permits any noncommercial use, distribution, and reproduction in any medium, provided the original author(s) and source are credited.

\section{References}

Altmann, J., \& Alberts, S. A. (1987). Body mass and growth rates in a wild primate population. Oecologia (Berlin), 72, 15-20.

Altmann, J., \& Muruthi, P. (1988). Differences in daily life between semi-provisioned and wild-feeding baboons. American Journal of Primatology, 15, 213-221.

Altmann, J., Altmann, S. A., Hausfater, G., \& McCuskey, S. A. (1977). Life history of yellow baboons: physical development, reproductive parameters and infant mortality. Primates, 18, 315-330.

Altmann, J., Schoeller, D., Altmann, S. A., Muruthi, P., \& Sapolsky, R. M. (1993). Body size and fatness of free-living baboons reflect food availability and activity levels. American Journal of Primatology, $30,149-161$.

Baker, M., \& Schutt, A. (2005). Managing monkeys and mangos. In J. D. Paterson \& J. Wallis (Eds.), Special topics in primatology (vol. 4). Commensalism and conflict: The human-primate interface (pp. 444 464). Norman: American Society of Primatologists.

Barrett, L., \& Henzi, S. P. (1997). Environmental determinants of body weight in chacma baboons. South African Journal of Science, 93, 436-438.

Bercovitch, F. B. (1987). Female weight and reproductive condition in a population of olive baboons (Papio anubis). American Journal of Primatology, 12, 189-195.

Bercovitch, F., \& Strum, S. C. (1993). Dominance rank, resource availability, and reproductive maturation in female savanna baboons. Behavioral Ecology and Sociobiology, 33, 313-318.

Biquand, S., \& Gautier, J. -P. (Eds.). (1994). Commensal primates. Revue d'Ecologie (La Terre et la Vie), 49, 213-222.

Biquand, S., Boug, A., Biquand-Guyot, V., \& Gautier, J.-P. (1994). Management of commensal baboons in Saudi-Arabia. Revue d'Ecologie (La Terre et la Vie), 49, 213-222.

Blankenship, L., \& Qvortrup, S. (1974). Resource management on a Kenya ranch. Journal of South African Wildlife Management Association, 4, 185-190.

Borgerhoff Mulder, M., \& Coppolillo, P. (2005). Conservation: Linking ecology, economics, and culture. Princeton: Princeton University Press.

Boulton, A. M., Horrocks, J. A., \& Baulu, J. (1995). Reevaluating the Barbados vervet monkey population and its role in crop damage. American Journal of Primatology, 36, 112.

Boulton, A. M., Horrocks, J. A., \& Baulu, J. (1996). The Barbados vervet monkey (Cercopithecus aethiops sabaeus): changes in population size and crop damage, 1980-1994. International Journal of Primatology, 17, 831-844.

Bourg, A., Biquand, S., Biquand-Guyot, V., \& Kamal, K. (1994). The response of commensal hamadryas baboons to seasonal reduction in food provisioning. Revue d'Ecologie (La Terre et la Vie), 49, 307319.

Bronikowski, A. M., \& Altmann, J. (1996). Foraging in a variable environment: weather patterns and the behavioral ecology of baboons. Behavioral Ecology Sociobiology, 39, 11-25. 
Caughley, G. (1977). Analysis of vertebrate populations. New York: Wiley.

Chakravarthy, A. K., \& Thyagaraj, N. E. (2005). Coexistence of bonnet monkeys (Macaca radiata radiata Geoffroy) with planters in the cardamom (Elettaria cardamum Maton) and coffee (Coffea arabica L.) plantations of Karnataka, South India: Hospitable or hostile? In J. D. Paterson \& J. Wallis (Eds.), Commensalism and conflict: The human-primate interface (pp. 270-293). Norman: American Society of Primatologists.

Chalise, M. K., \& Johnson, R. L. (2005). Farmer attitudes toward the conservation of "pest" monkeys: the view from Nepal. In J. D. Paterson \& J. Wallis (Eds.), Commensalism and conflict: The humanprimate interface (pp. 222-239). Norman: American Society of Primatologists.

Chism, J. (2005). Round up the usual suspects - conflict between monkeys and farmers in East and West Africa. In J. D. Paterson \& J. Wallis (Eds.), Commensalism and conflict: The human-primate interface (pp. 338-349). Norman: American Society of Primatologists.

Conover, M. (2002). Resolving human-wildlife conflicts: The science of wildlife damage management. Boca Raton: CRC.

Cowlishaw, G., \& Dunbar, R. (2000). Primate conservation biology. Chicago: The University of Chicago Press.

Diamond, J. (1984). "Normal" extinction of isolated populations. In M. J. Nitecki (Ed.), Extinctions (pp. 191-246). Chicago: University of Chicago Press.

Diamond, J. (1989). Overview of recent extinctions. In D. Western \& M. Pearl (Eds.), Conservation for the twenty-first century (pp. 37-41). New York: Oxford University Press.

Dunbar, R. (1988). Primate social systems. London: Chapman and Hall.

Eley, R. M., Strum, S. C., Muchemi, G., \& Reid, G. D. F. (1989). Nutrition, body condition, activity patterns, and parasitism of free-ranging troops of olive baboons (Papio anubis) in Kenya. American Journal of Primatology, 18, 209-219.

Else, J., Lee, P. C., \& Brennan, E. J. (1986). Ecology and behaviour of vervet monkeys at a tourist lodge. Primate Ecology and Conservation, 3, 229-235.

Fa, J. E. (1988). Supplemental food as an extranormal stimulus in Barbary Macaques (Macaca sylvanus) at Gibraltar-Its impact on activity budgets. In J. E. Fa \& C. Southwick (Eds.), Ecology and behavior of food enhanced primates (pp. 53-78). New York: Liss.

Fa, J. E., \& Southwick, C. (Eds.). (1988). Ecology and behavior of food enhanced primate groups. New York: Liss.

Fedigan, L., \& Zohar, S. (1997). Sex differences in mortality of Japanese macaques: twenty one years of data from the Arashiyama West population. American Journal of Physical Anthropology, 102, 161-175.

Fitzgibbon, D. C., Mogaka, H., \& Fanshawe, J. H. (1995). Subsistence hunting in Arabuko-Sokoke Forest, Kenya, and its effects on mammal populations. Conservation Biology, 9, 1116-1126.

Forthman, D. L. (1986a). Controlling primate pests: the feasibility of conditioned taste aversion. In D. M. Taub \& F. A. King (Eds.), Current perspectives in primate social dynamics (pp. 252-273). New York: Van Nostrand Reinhold.

Forthman, D. L. (1986b). Activity budgets and the consumption of human food in two troops of baboons, Papio anubis, at Gigil, Kenya. In J. Else \& P. C. Lee (Eds.), Primate ecology and conservation (pp. 221-228). New York: Cambridge University Press.

Forthman, D. L., Strum, S. C., \& Muchemi, G. (2005). Applied conditioned taste aversion and the management and conservation of crop-raiding primates. In J. D. Paterson \& J. Wallis (Eds.), Commensalism and conflict: The human-primate interface (pp. 420-443). Norman: American Society of Primatologists.

Forthman-Quick, D. L., \& Demment, M. (1988). Dynamics of exploitation: Differential energetic adaptations of two troops of baboons to recent human contact. In J. E. Fa \& C. Southwick (Eds.), Ecology and behaviour of food enhanced primate groups (pp. 25-51). New York: Liss.

Fuentes, A., \& Wolfe, L. D. (2002). Primates face to face: Conservation implications of human-nonhuman primate interconnections. New York: Cambridge University Press.

Harding, R. S. O. (1976). Ranging patterns of a troop of baboons (Papio anubis) in Kenya. Folia Primatologica, 25, 143-185.

Hill, C. M. (1997). Crop-raiding by wild vertebrates: the farmer's perspective in an agricultural community in western Uganda. International Journal of Pest Management, 43, 77-84.

Hill, C. M. (2000). Conflict of interest between people and baboons: crop raiding in Uganda. International Journal of Primatology, 21, 299-315.

Hill, C. M. (2005). People, crops and primates: A conflict of interests. In J. D. Paterson \& J. Wallis (Eds.), Commensalism and conflict: The human-primate interface (pp. 40-59). Norman: American Society of Primatologists. 
Horrocks, J. A., \& Baulu, J. (1988). Effects of trapping on the vervet (Cercopithecus aethiops sabaeus) population in Barbados. American Journal of Primatology, 15, 223-233.

Horrocks, J. A., \& Baulu, J. (1994). Food competition between vervets (Cercopithecus aethiops sabaeus) and farmers in Barbados: implications for management. Revue d'Ecologie (Terre et la Vie), 49, 281-294.

Kansky, R. (2002). Baboons on the Cape Peninsula: A guide for residents and visitors. Report: International Fund for Animal Welfare (IFAW).

Kemnitz, J. W., Sapolsky, R. M., Altmann, J., Muruthi, P., Mott, G. E., \& Stefanick, M. L. (2002). Effects of food availability on serum insulin and lipid concentration in free-ranging baboons. American Journal of Primatology, 57, 13-19.

Lee, P. C., \& Priston, N. E. C. (2005). Perception of pests: Human attitudes to primates, conflict and consequences for conservation. In J. D. Paterson \& J. Wallis (Eds.), Commensalism and conflict: The human-primate interface (pp. 1-23). Norman: American Society of Primatologists.

Lee, P. C., Brennan, E. J., Else, J. G., \& Altmann, J. (1986). Ecology and behaviour of vervet monkeys in a tourist lodge habitat. In J. Else \& P. C. Lee (Eds.), Primate ecology and conservation (pp. 229-235). Cambridge: Cambridge University Press.

Malik, I., \& Johnson, R. L. (1994). Commensal rhesus in India. Revue d'Ecologie (La Terre et la Vie), 49, 233-243.

Muruthi, P., Altmann, J., \& Altmann, S. A. (1991). Resource base, parity and reproductive condition affect female feeding time and nutrient intake within and between groups of a baboon population. Oecologia, 87, 467-472.

Musau, J., \& Strum, S. C. (1984). Response of wild baboon troops to the incursion of agriculture at Gilgil. International Journal of Primatology, 5, 364.

Naughton-Treves, L. (1998). Predicting patterns of crop damage by wildlife around Kibale National Park. Conservation Biology, 12, 156-168.

Naughton-Treves, L., \& Treves, A. (2005). Socio-ecological factors shaping local support for wildlife: crop-raiding by elephants and other wildlife in Africa. In R. Woodroffe, S. Thirgood, \& A. Rabinowitz (Eds.), People and wildlife: Conflict or coexistence? (pp. 252-277). Cambridge: Cambridge University Press.

Naughton-Treves, L., Treves, A., Chapman, C., \& Wrangham, R. (1998). Temporal patterns of cropraiding by primates: linking food availability in croplands and adjacent forest. Journal of Applied Ecology, 35, 596-606.

Oates, J. F. (1999). Myth and reality in the rain forest: How conservation strategies are failing in West Africa. Berkeley: University of California Press.

Oelschlaeger, M. (1991). The idea of wilderness. New Haven: Yale University Press.

Onderdonk, D. A., \& Chapman, C. (2000). Coping with forest fragmentation: the primates of Kibale National Park, Uganda. International Journal of Primatology, 21, 587-611.

Osborn, F. V., \& Hill, C. M. (2005). Techniques to reduce crop loss: Human and technical dimensions in Africa. In R. Woodroffe, S. Thirgood, \& A. Rabinowitz (Eds.), People and wildlife: Conflict or coexistence? (pp. 72-85). Cambridge: Cambridge University Press.

Oyaro, J., \& Strum, S. C. (1984). Shifts in foraging strategies as a response to the presence of agriculture. International Journal of Primatology, 5, 371.

Paterson, J. D. (2005a). Preface. In J. D. Paterson \& J. Wallis (Eds.), Commensalism and conflict: The human-primate interface (pp. xv-xvii). Norman: American Society of Primatologists.

Paterson, J. D. (2005b). Residents and immigrants: reactions and perceptions of crop raiding in Masindi District, Uganda. In J. D. Paterson \& J. Wallis (Eds.), Commensalism and conflict: The humanprimate interface (pp. 76-89). Norman: American Society of Primatologists.

Paterson, J. D., \& Wallis, J. (Eds.). (2005). Special topics in primatology (vol. 4): Commensalism and conflict: The human-primate interface. Norman: American Society of Primatologists.

Primack, R. (2006). A primer of conservation biology. Sunderland: Sinauer.

Richard, A. F., Goldstein, S. J., \& Dewar, R. E. (1989). Weed macaques: the evolutionary implications of macaque feeding ecology. International Journal of Primatology, 10, 569-594.

Rose, A. L. (2002). Conservation must pursue human-nature biosynergy in the ear of social chaos and bushmeat commerce. In A. Fuentes \& L. D. Wolfe (Eds.), Primates face to face: The conservation implications of the human-nonhuman primate interconnections (pp. 208-239). Cambridge: Cambridge University Press.

Saj, T., Sicotte, P., \& Paterson, J. D. (1999a). Age-sex class differences in the time budget and feeding strategies of members of a crop and food-raiding vervet group in Entebbe, Uganda. American Journal of Primatology, 49, 96-97. 
Saj, T., Sicotte, P., \& Paterson, J. D. (1999b). Influence of human food consumption on the time budget of vervets. International Journal of Primatology, 20, 977-994.

Saj, T., Sicotte, P., \& Paterson, J. D. (2001). The conflict between vervet monkeys and farmers at the forest edge in Entebbe, Uganda. African Journal of Ecology, 39, 195-199.

Siex, K. S. (2005). Habitat destruction, population compression and overbrowsing by the Zanzibar red colobus monkeys (Procolobus kirkii). In J. D. Paterson \& J. Wallis (Eds.), Commensalism and conflict: The human-primate interface (pp. 294-337). Norman: American Society of Primatologists.

Smuts, B. (1985). Sex and friendship in baboons. New York: Aldine.

Smuts, B., \& Nicholson, N. (1989). Reproduction in wild female olive baboons. American Journal of Primatology, 19, 229-246.

Sprague, D. S. (2002). Monkeys in the backyard: Encroaching wildlife and rural communities in Japan. In A. Fuentes \& L. Wolfe (Eds.), Primates face to face: The conservation implications of humannonhuman primate interconnections (pp. 254-272). Cambridge: Cambridge University Press.

Statsoft. (2005). Tulsa: Statistica.

Strum, S. C. (1975). Primate predation: Interim report on the development of a tradition in a troop of olive baboons. Science, 187, 755-757.

Strum, S. C. (1987). Almost human: A journey into the world of baboons. Chicago: University of Chicago Press.

Strum, S. C. (1991). Weight and age in wild olive baboons. American Journal of Primatology, 25, 219237.

Strum, S. C. (1993). Reconciling aggression and social manipulation as means of competition, part 1: Lifehistory perspective. International Journal of Primatology, 91, 387-389.

Strum, S. C. (1994). Prospects for management of primate pests. Revue d'Ecologie (La Terre et la Vie), 49, 295-306.

Strum, S. C. (2005). Measuring success in primate translocation: a baboon case study. American Journal of Primatology, 65, 117-140.

Strum, S. C., \& Western, J. D. (1982). Variations in fecundity with age and environment in a baboon population. American Journal of Physical Anthropology, 3, 61-76.

Strum, S. C., \& Southwick, C. (1986). Translocation of primates. In K. Benirschke (Ed.), Primates: The road to self-sustaining populations (pp. 949-958). New York: Springer-Verlag.

Strum, S. C., \& Fedigan, L. M. (2000). Changing views of primate society: A situated North American view. In S. C. Strum \& L. M. Fedigan (Eds.), Primate encounters: Models of science, gender and society (pp. 3-49). Chicago: University of Chicago Press.

Survey of Kenya, D. O. S. (1975). East Africa 1:50,000 (Kenya). In D. O. S. 423 (Ed.), Y731/sheet 119/4. Gilgil: Government of Kenya.

Tarara, R., Suleman, M. A., Sapolsky, R., Wabomba, M. J., \& Else, J. G. (1985). Tuberculosis in wild olive baboons, Papio cynocephalus anubis (lesson), in Kenya. Journal of Wildlife Diseases, 21, 137140.

Terborgh, J., van Schaik, C., Davenport, L., \& Rao, M. (Eds.). (2002). Making parks work: Strategies for preserving tropical nature. Washington: Island.

Thomas, K. (1983). Man and the natural world: A history of the modern sensibility. New York: Pantheon Books.

Treves, A., \& Naughton-Treves, L. (2005). Evaluationg lethal control in the management of humanwildlife conflict. In R. Woodroffe, S. Thirgood, \& A. Rabinowitz (Eds.), People and wildlife: conflict or coexistence? (pp. 86-106). Cambridge: Cambridge University Press.

Vitousek, P. M., Mooney, H. A., Lubchenco, J., \& Melillo, J. M. (1997). Human domination of Earth's ecosystems. Science, 277, 494-499.

Warren, Y., Buba, B., \& Ross, C. (2007). Patterns of crop-raiding by wild and domestic animals near Gashaka Bumti National Park, Nigeria. International Journal of Pest Management, 53, 207-216.

Western, D., Wright, M., \& Strum, S. C. (Eds.). (1994). Natural connections: Perspective in communitybased conservation. Washington: Island.

Woodroffe, R., Thirgood, S., \& Rabinowitz, A. (2005). People and wildlife: Conflict or coexistence? Cambridge: Cambridge University Press. 